This item was submitted to Loughborough's Research Repository by the author.

Items in Figshare are protected by copyright, with all rights reserved, unless otherwise indicated.

\title{
Discursive social psychology: from attitudes to evaluative practices
}

PLEASE CITE THE PUBLISHED VERSION

http://dx.doi.org/10.1080/14792779843000090

PUBLISHER

(c) Taylor and Francis

VERSION

AM (Accepted Manuscript)

LICENCE

CC BY-NC-ND 4.0

REPOSITORY RECORD

Potter, Jonathan. 2019. "Discursive Social Psychology: From Attitudes to Evaluative Practices". figshare. https://hdl.handle.net/2134/9528. 
This item was submitted to Loughborough's Institutional Repository (https://dspace.lboro.ac.uk/) by the author and is made available under the following Creative Commons Licence conditions.

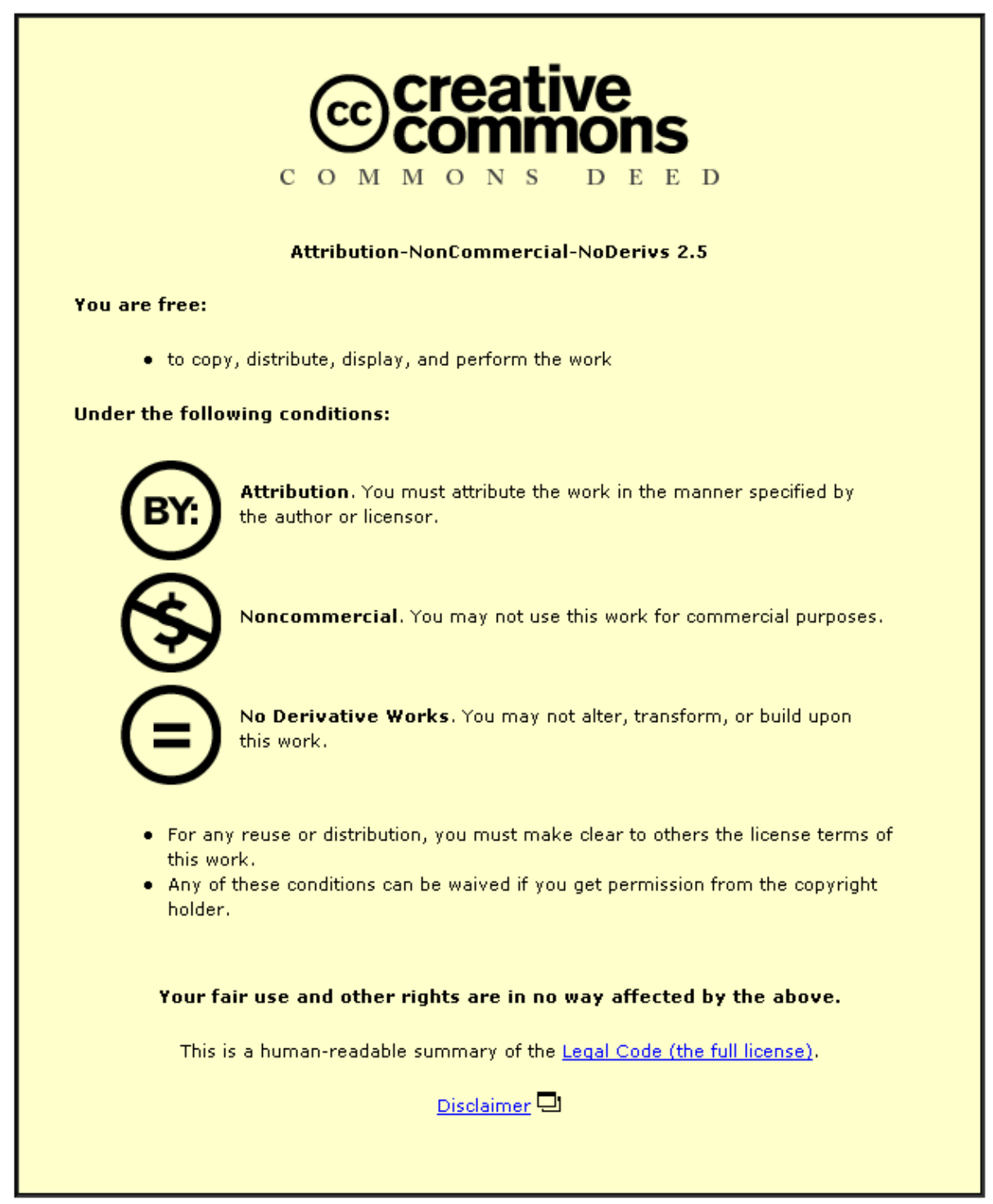

For the full text of this licence, please go to: http://creativecommons.org/licenses/by-nc-nd/2.5/ 


\section{Discursive Social Psychology:}

\section{From Attitudes to Evaluative Practices}

\section{Jonathan Potter}

Discourse and Rhetoric Group

Department of Social Sciences

Loughborough University

Loughborough

Leicestershire, LE11 3TU
Email: J.A.Potter@lboro.ac.uk

Tel: $\quad 01509223384$

Fax: 01509223944

Published as:

Potter, J. (1998). Discursive social psychology: From attitudes to evaluations, European Review of Social Psychology, 9, 233-266.

I would like to thank Charles Antaki, Michael Billig, Derek Edwards and Margaret Wetherell, for their comments on an earlier draft of this article, as well as the Miles Hewstone, Wolfgang Stroebe and two anonymous referees. 


\begin{abstract}
This chapter reviews the major theoretical and methodological features of discursive social psychology, and illustrates the scope and nature of this approach through showing the way it can respecify the social psychology of attitudes. It reviews discourse research on attitude variability; it describes conversation analytic studies on the way evaluations are managed in interaction and shows how our understanding of political oratory can be improved; it discusses the way evaluations are bound up with broader, culturally defined, systems of discourse; it discusses the relation between assessments and factual accounts; and finally it shows how a discursive approach can rework notions of function, consistency, vested interest, and emotion.
\end{abstract}


The aim of this chapter is to introduce a discursive approach to social psychology to people who are more familiar with the mainstream experimental social cognition tradition. After making some preliminary remarks about the history, aims and theory of discursive social psychology I will focus on what would traditionally be called the social psychology of attitudes. This topic has the virtue of being at the heart of social psychology for much of the century, and thus provides a familiar startpoint for anyone wishing to understand what is distinctive about the discursive approach, and how radical its respecification of traditional notions will be.

\section{DISCURSIVE SOCIAL PSYCHOLOGY}

Discursive social psychology is the application of ideas from discourse analysis to issues in social psychology. Its publication record goes back over a decade. The first analytic article published in a social psychological journal was in 1985 (Litton and Potter, 1985) and one of the major stimuli for the development of the approach was the book Discourse and Social Psychology (Potter and Wetherell, 1987). This parallels the development of a rhetorical approach to social psychology, whose first analytic article was published in 1985 (Billig, 1985) and whose major theoretical introduction, Billig's Arguing and Thinking, was also published in 1987 (now Billig, 1996). Since the end of the 1980s these two approaches have blurred together, and there has been a related interest in drawing on ideas from the perspective of conversation analysis (Atkinson and Heritage, 1984; Sacks, 1992) and applying them to social and cognitive psychological issues (Edwards, 1991, 1997; Edwards and Potter, 1993; Antaki, 1994). In this chapter, unless I explicitly claim otherwise, I am using the name discursive social psychology to refer to a set of ideas and developments from discourse analysis, conversation analysis and rhetoric. 
Work of this kind has mushroomed in the last few years across a wide range of disciplines and analytic topics. It has been concentrated particularly in UK, but notable developments have taken place in Australia, Canada, Italy, The Netherlands, New Zealand, Scandinavia, and Spain. In this chapter, the focus will be specifically social psychological, and I will ignore developments and debates in sociology and linguistics, as well as the issues which distinguish the form of discourse analysis discussed here from variants which evolved in linguistics (Brown and Yule, 1983), sociolinguistics (Sinclair and Coulthard, 1975), poststructuralism (Foucault, 1971) and cognitive psychology (van Dijk and Kintsch, 1983). Some of the differences between these approaches are summarized briefly in Potter (1996a) and explored in detail in Schiffrin (1994) and van Dijk (1996).

\section{Theoretical and Meta-theoretical Characteristics of Discursive Social Psychology}

Although the development of discursive social psychology was facilitated by the 'climate of problematization' (Curt, 1994) engendered by the so called 'crisis in social psychology' in the 1970s (Parker, 1989), and the intellectual space cleared by the work of Gergen (1973), Harré and Secord (1972), and Shotter (1977), its direct theoretical and analytic antecedents were developments in sociology of scientific knowledge (Gilbert and Mulkay, 1984), ethnomethodology and conversation analysis (Garfinkel, 1967; Sacks, 1992) and a range of notions from post-structuralism and particularly the work of Foucault and Barthes. Discursive social psychology is a broadly constructionist perspective and is commonly, although not always, associated with a relativist meta-theory rather than the realist, positivist metatheory that is still commonplace in experimental social psychology (Edwards et al., 1995; Gergen, 1994). 
Discursive social psychology is constructionist in two senses. On the one hand, it takes people to be constructing their worlds through their accounts and descriptions. That is, 'reality' enters human practices by way of the categories and descriptions that are parts of those practices. The world is not already categorized by God or nature in a way that must be passively accepted; rather, it is constituted in one way or another as people talk it, write it, argue it and undermine it. On the other hand, discursive social psychology stresses that these descriptions and accounts that people use to constitute their worlds are themselves constructed; that is, fabricated in occasions of talk, or in specific texts, from words, metaphors, and a range of discursive resources. This twin sense of construction marks out part of the subject matter of discursive social psychology: it researches the practices that are sustained by particular constructions of the world (accounts, descriptions); and it researches how those descriptions are built, how they are fitted to their context of use, and the resources they draw on (Potter, 1996b).

Discursive social psychology's constructionism is closely related to its relativist metatheory. The emphasis on accounts and descriptions being built as parts of human practices has encouraged discourse analysts to consider the practices through which scientific 'findings' are produced and the texts in which those findings are represented and warranted. That is, they have emphasised the requirement and virtue of reflexively considering the implications of research for science in general, and for scientific and social scientific texts, including social science texts such as this very one I am writing now (Ashmore, 1989; Mulkay, 1985). Some of the consequences and issues raised by relativist work, and its relation to broader themes in postmodernism, are discussed in Gergen $(1991,1994)$, Potter (1996b, forthcoming a) and Shotter (1993a,b). It is important to note, however, that not all researchers combine a discursive approach to social psychology with a relativist meta-theory (Billig, 1991; Gill, 1995; Harré, 1992; Parker, 1992). 
For some years social psychologists have looked increasingly to social cognition for explanatory phenomena; the paraphernalia of scripts, schemas, heuristics, attitudes, beliefs, social representations, memory stores, categories, prototypes, and so on (Fiske and Taylor, 1991). These become the players in a more general story that casts people as information processors sifting and computing input and generating a range of outputs. In contrast, the central theoretical thrust of discursive social psychology is anti-cognitivist. This does not mean that nothing is assumed to be going on under people's skulls. Rather, discursive social psychology is moving both the analytic and explanatory focus from cognitive processes and entities to discursive practices and the resources they draw on (Edwards, 1997). That is, it studies activity itself — rather than the outcomes of activity or reports of activity, as is more common in mainstream social psychology. For example, rather than taking a measure of 'opinion shift' before and after a group discussion, or getting participants to rate the conversation on a series of scales, the discussion itself will be studied in the form of a video/audio tape and transcript (McKinlay, 1988).

Discursive social psychologists have overwhelmingly worked with two kinds of materials. For much of the 1980s their primarily focus was on open ended interviews. More recently, they have increasingly worked on records of natural interaction or natural texts: newspaper reports, relationship counselling sessions, police interviews, social workers' talk with clients, transcripts of everyday talk, and so on. However, the contrast between interviews and records of natural interaction is not as great as might appear; for interviews are not being treated as a neutral machinery for harvesting psychologically interesting responses but as arenas of interaction in their own right, where the interviewer and interviewee's contributions are equally important (Potter and Mulkay, 1985; Widdicombe and Wooffitt, 1995). The point to emphasise is that discursive social psychology studies interaction done 
through talk and texts and considers how that interaction is done, and what resources it draws on, and how these things relate to broader questions in social psychology.

Relating Theoretical and Methodological Characteristics of Discursive Social Psychology

It is important to emphasise at the outset that discursive social psychology has a strongly empirical focus. It is not attempting to replace empiricism with theory or speculation or politics. Rather, the emphasis is on producing a rigorous analytic programme of mainly qualitative research where theoretical claims are closely related to systematic research studies. Nevertheless, it is hard to overestimate how different the analytic approach is from mainstream social psychology. This difference in method is closely related to distinctive theoretical elements in discursive social psychology. Let me give three examples to illustrate this.

First, discursive social psychology has not adopted the factors and outcomes notions that are closely bound up with traditional social psychological research, and its use of experiments and questionnaires. Rather than viewing social life as a consequence of an interplay of factors which have more or less regular patterns and determinate outcomes, discursive social psychology conceptualizes social life as both normative and rhetorical.

Norms are treated as oriented to rather than governing action, so that we would expect to find regular deviations, although such deviations may themselves be marked by a range of accounts and sanctions and will therefore be inferentially rich (Heritage, 1984, 1988; Sacks, 1992; Wooffitt, 1990). Take the example of a greeting. People have the expectation that a greeting will be returned; 'hello' will be responded to by 'oh hi' — this is the normal thing to do. However, this does not mean that when a greeting is not returned people start to doubt the normative basis of greeting. Instead they are likely to engage in a range of inferences 
about the person or the context: they are rude, hard of hearing, sulking or whatever which will be displayed in their response to the non-returned greeting.

Rhetoric is treated in discursive social psychology as oriented to persuasion. The point of describing it like this is to emphasise that however good the rhetoric there is no guarantee that persuasion takes place. For example, a rhetorical move can have a range of rhetorical counter moves. In an argument about race, a categorization, say, can be countered by particularization (Billig, 1985); or in a relationship counselling dispute a man criticised for pathological jealousy may turn the negative potential of that description around and argue that his partner is insensitive to his jealousy problem (Edwards, 1995).

The analytic point that flows from this is that it is not sufficient to identify a norm, or some rhetoric, independently of the practices that they are part of. This is why discursive social psychologists have focused on practices whether it is the conversational interaction found in interviews, talk in a range of everyday or institutional settings, or texts such as newspaper articles or literary narratives.

The second point is closely related to the first. The goal of discursive social psychology is not to look beyond the apparent messiness of interaction to discover general patterns and laws lying beyond it; rather, it is focused on the specific detail of interaction and how that detail is precisely related to the activities that are being performed. The conversation analyst Sacks (1992) suggested that none of the detail of interaction, whether it be pauses and repairs, the selection of particular words, or the placement of interruption and overlaps, should be assumed to be irrelevant to interaction. The negative construction here is quite deliberate. The argument is not that a sniff, say, must always be related to the business of the current interaction rather than being a consequence of having a runny nose; it is that we should not assume that a sniff does not have the potential for doing interactional business, such as indirectly displaying disagreement (Roffe, 1997). 
Discursive social psychologists, then, work at a level of analysis where much of the concern is with the specifics of what was said, the co-ordination of actions, the design of undercutting accounts and so on. However, this does not mean that their concern is merely with more 'micro' features of interaction, at least as that notion has traditionally been understood in social science. For it is often at the level of specific arguments or detailed conversational patterns that 'micro' issues of ideology, social structure and social setting become important (e.g. Billig et al., 1988; Boden, 1994; Heath, 1992). Indeed, there has recently been dynamic debate reconceptualizing issues of talk, interaction and social structure (Boden and Zimmerman, 1991; Drew and Heritage, 1992).

The third point of difference from traditional research is that discursive social psychologists place less value on hypothetico-deductivism. The quality of discursive research is not taken to depend on the prior formulation of a specific question or a precisely specified hypothesis. Instead it has often been productive to collect and explore a set of materials without being constrained by a specific hypothesis. Part of the reason for this is that close attention to a video and transcript often reveal phenomena that were both previously unnoticed and unexpected. Starting with the materials rather than prior hypotheses is a way of allowing such phenomena into the analysis.

This is not to endorse naive inductionism, however. Such materials will be analysed against a backdrop of general theoretical concerns as well as specific research themes; a concern with racism say, or the use of descriptions in relationship counselling. Nor is it to reject hypothetico deductivism in toto. At times the process of analysing discourse can involve following up and checking hypotheses about the role and nature of particular constructions or forms of interaction.

One way of conceiving the general methodological orientation of discursive social psychology is by analogy with the disciplines of ethology and astronomy. Both are 
observational rather than experimental sciences. Both are fields where careful and systematic description provides a foundation for broader theoretical claims. And both are fields where the documentation of specific individual phenomena - tactical deception in a primate, perturbations in a planet's orbit — can be crucial for assessing the adequacy of general claims and theoretical systems.

Methodological Procedures in Discursive Social Psychology

There are a range of published accounts of different methodological and analytic aspects of discursive social psychology (Billig, 1997; Coyle, 1995; Gill, 1996; Potter, 1996c, 1997, forthcoming b; Potter and Wetherell, 1987, 1994, 1995; Wetherell and Potter, 1992; Wooffitt, 1990, 1993; Widdicombe and Wooffitt, 1995). It is important to remember at this point that discursive social psychology is new approach with a range of different strands to it. Although the references cited here are show broad agreement, there is also methodological writing from a more Foucaultian perspective (Parker, 1992) and a more conversation analytic perspective (Drew, 1995) which offers rather different methodological precepts.

The aim in this current article is not to duplicate this work but to highlight some of the features that are common in discursive social psychology to highlight its differences from work in the more familiar experimental tradition. To simplify discussion I will focus on three elements of the work: (a) research materials; (b) analysis; and (c) validation procedures.

(a) Research Materials. Traditional social psychologists have been reluctant to deal with actual interaction, preferring to model it experimentally or reconstruct it via scales and questionnaires. Part of the reason for this has been the prevalent cognitive assumptions which have directed the research focus away from interaction and on to generative mechanisms within the person. In contrast to this discursive social psychologists have 
emphasised the primacy of practices themselves, and have therefore focused on conversational interaction in interviews or natural settings, or documents of various kinds.

Where interaction is the focus it is taped, either on audio or video, and transcribed. As discursive social psychology has developed the need for high quality transcription has become more fully recognized. The best and most widely used system was developed by the conversation analyst Gail Jefferson and uses symbols that convey features of vocal delivery that have been shown to be interactionally important to participants. A summary of the system is reproduced in the appendix - a fuller description can be found in Ochs, Schegloff and Thompson (1996).

(b) Analysis. There is no single simple recipe for analysing discourse. However, most analysis involves a period of coding which is principally designed to make the task of analysis simpler by sifting relevant materials from a larger body of transcript or documents and copying them into an archive. Such coding is inclusive and cyclical. It is not meant to prejudge analytic conclusions by eliminating potential instances prior to analysis. The process of analysis will often lead the researcher back to the original corpus as a better understanding of relevant phenomenon suggests new examples. Preliminary coding of this kind differs from traditional content analysis (Krippendorf, 1980) where coding, and statistical manipulations, constitute the analysis itself.

Discourse analysis is a craft which is developed with vary degrees of skill. One useful way of conceptualizing analysis is as dependent on the development of an analytic mentality which is sensitive to a range of features of discourse. Elements that have been found to be revealing include: variability in and between different texts and stretches of talk; the detail of hesitations, repair, lexical choice and so on; the rhetorical organization of discourse (how it is constructed to counter alternatives); and its accountability. Most analysis, whatever its overall goal, benefits from a good understanding of features of mundane conversational 
organization such as turn taking, adjacency pairs, repair, and preference organization (Levinson, 1983; Nofsinger, 1991; Schegloff, 1997).

(c) Validation Procedures. Discourse researchers typically draw on some combination of four considerations to justify the validity of analytic claims. First, they make use of participants' own understandings as they are displayed in interaction. One of the features of a conversation is that any turn of talk is orientated to what came before and what comes next, and that orientation typically displays the sense that the participant makes of the prior turn. Thus, at its simplest, when someone provides an answer they thereby display the prior turn as a question and so on. Close attention to this turn-by-turn display of understanding provides one important check on analytic interpretations (see Heritage, 1988). Some of the same considerations can be drawn on when dealing with single narratives or with texts (Edwards \& Potter, 1992a; Wooffitt, 1992).

Second, researchers may find (seemingly) deviant cases most useful in assessing the adequacy of a claim. Deviant cases may generate problems for a claimed generalization, and lead the researcher to abandon it; but they may also display in their detailed organization precisely the reason why a standard pattern should take the form that it does (Heritage, 1995). For example, the claim that participants in television and radio news interviews normally avoid treating interviewers as accountable for views expressed in questions can be supported through detailed analysis of deviant cases where considerable trouble is produced by interviewees treating their interviewer as expressing their own views (Heritage \& Greatbatch, 1991; Potter, 1996b).

Third, a study may be assessed in part by how far it is coherent with previous discourse studies. A study that builds coherently on past research is more plausible than one that is more anomalous. For example, work on fact construction builds on the insights about accountability from earlier studies, and its success provides a further confirmation of the 
validity of those studies (Edwards and Potter, 1993). There is a sense, then, that each new study provides a check on the adequacy of previous studies that are drawn on. Those studies which capture something about interaction can be built on, those that do not are likely to become ignored.

Fourth, and most important, are readers evaluations. One of the distinctive features of discourse research is its presentation of rich and extended materials in a way that allows the reader to make their own judgements about interpretations that are placed along side of them. This form of validation contrasts with much traditional experimental and content analytic work where it is rare for 'raw' data to be included or more than one or two illustrative codings to be reproduced.

Whether they appear singly or together in a discourse study none of these procedures guarantee of the validity of an analysis. However, work in philosophy and sociology of science over the past thirty years has cast doubt on the possibility of such bottom-line guarantees in science whether provided by observation, replication, or experimentation (Chalmers, 1992; Collins, 1985; Woolgar, 1988).

\section{DISCOURSE AND ATTITUDES}

One of the features of discursive social psychology is that it provides a root and branch respecification of a broad range of social psychological notions (Potter and Wetherell, 1987). By starting with the notion of attitudes it would be easy to give the impression that there are pre-existing objects — attitudes — which are understood in one way, or one set of ways, in mainstream social cognition work, and then understood in another way in discursive social psychology. However, this would understate the degree to which the attitude notion is 
constituted out of social psychological theory, and the extent to which the notion is dissolved in discursive social psychology into a range of other considerations.

Before going on to describe various strands of research that underpin this dissolution it is important to note three things. First, compared with the mountain of mainstream work on attitudes, there is only a small amount of discursive work which relates to the topic. Second, as I noted above, the criteria for what counts as good research in this area are rather different than in mainstream social psychology. Third, there is a strong emphasis on theoretical and conceptual development in this area; the balance between theorizing and researching is tipped rather more in the direction of theory than is common in mainstream work.

My discussion will follow six themes. First, it will provide a general account of the way discursive social psychology would deal with phenomena traditionally collected under the notion of attitudes. Second, it will review work on attitude variability and the problems it raises for standard notions of attitudes. Third, it will describe some research from a conversation analytic perspective that has considered some of the practices through which evaluations are expressed in everyday settings and in political speeches. Fourth, it will overview some research which shows the way evaluations are bound up with broader systems of discourse or interpretative repertoires. Fifth, it will discuss the relation between making assessments and the construction of factual accounts. Sixth, and finally, it will consider how a number of the notions and variables that have been emphasised in recent and classic attitude research are respecified in discursive social psychology. This will focus in particular on function, consistency, vested interest and emotion. 


\section{Discourse and Evaluation}

A discursive approach to evaluation will involve a number of key moves. In the first place, it will shift from considering attitudes as underlying mental constructs to focusing on people's practices of evaluation in particular settings. The term practice here is crucial; for the stress in discursive social psychology is on what is done with evaluations - their practical use, explicit or indirect — rather than their potential as an index of individual differences or as a predictor of later actions. Discursive social psychology treats action as fundamental or, as Schegloff (1995) puts it, omnirelevant. So if you want to understand evaluations you need to consider carefully what people are doing with them in their 'home' environments rather than in the more arcane contexts of filling in attitude scales.

The second move is closely related to the first, and involves considering evaluations as they are constructed and understood by participants rather than attempting to produce a technical definition which will improve on participants' understandings. Using the anthropological distinction, traditional attitude social psychology is an etic approach where the analytic categories are refined with the aim of giving an increasingly precise and consistent psychologists' account of how attitudes should be understood. In contrast, discursive social psychology is an emic approach where the topic is how evaluation is constituted in varied ways in participants practices. The aim is not to improve on participants' practices and understandings but to explicate their nature. That is, it is not designed to provide a more precise and unambiguous style of evaluation, but to understand how everyday evaluations with all their contradictions and ambiguities are used.

The third move is to develop an approach which accommodates to a wide range of different practices involving evaluation (some using the familiar language of attitudes and opinions, some not). Rather than assume that there is a single underlying logic, discursive 
social psychology will treat this heterogeneity as a potentially consequential and constitutive feature of such practices. The significance of this move can be illustrated by considering the manner in which attitudes are measured in recent social psychological research.

One commonplace technique of attitude measurement, particularly in the tradition associated with Fishbein and Azjen (1975; Azjen, 1988) uses semantic differential scales. These vary in number, point size, and content according to the study. Some haphazardly collected examples include: enjoyable-unenjoyable, good-bad, foolish-wise, harmfulbeneficial, pleasant-unpleasant (Sparks et al., 1992), good-bad, desirable-undesirable, positive-negative, beneficial-harmful (Prislin, 1996), worrying-reassuring, unpleasantpleasant, punishing-rewarding, unenjoyable-enjoyable, useless-useful (Norman and Smith, 1995), and extremely good-extremely bad, like extremely-dislike extremely (Berger, 1992). Note that apart from the three occurrences of good-bad these words are all different. Nevertheless, they are taken to be measuring one thing: the person's underlying attitude to eating biscuits, exercise, legalised abortion, a new chocolate bar or whatever the relevant attitude object was.

From the perspective of discursive social psychology the issue is not whether people are able to perform the task of filling in semantic differential scales related to a particular object; clearly they can make enough sense of it to provide scores for the researcher. Rather it is the theory of language underlying this approach. Instead of assuming that there is a single underlying evaluation that can be expressed by scales attached to a number of different words it suggests that we consider the specifics of the words used in these scales and their practical use.

Take, for example, the simplest of attitude measures (used by Berger, 1992) which involves just two scales: extremely good-extremely bad, like extremely-dislike extremely. These seem straightforward enough and it is not a surprise that Berger obtains a score of 
internal consistency (alpha) of .92 for judgements about a new chocolate bar. However, this does not mean that the words 'good' and 'like' are interchangeable in ordinary discourse. It is not hard to imagine uses in which the two conflict: 'Independence Day was a bad movie, but I liked it' is a perfectly coherent thing to say; the word 'bad' picks out the film's intrinsic merit, while 'like' indexes something about the person. One way of thinking about this is that 'good' is a word which involves public, shared or at least defensible criteria, while 'like' is a personal claim that can be explicated, but does not require justification in the same way. This can be seen we consider a disagreement in each case. It is perfectly sensible to disagree with someone who has claimed that Independence Day is a bad film, and various reasons could be offered for and against. However, it would be rather peculiar to claim that the person who said they liked it is wrong, that really they disliked it. Liking is typically treated as something a person has privileged knowledge of; if liking is denied this would not by to suggest that the person was mistaken but to suggest that they were lying (to ingratiate themselves, perhaps).

I am not wanting to suggest that discursive social psychology should perform abstract conceptual analysis of terms such as these. Such analyses can be revealing (Mulhausler \& Harré, 1990; Sabini and Silver, 1982); yet they can easily underestimate the complexity and rhetorical flexibility of everyday discourse, as Edwards (1997) argues with the case of emotion. The point I am making is that traditional attitude measurement blurs potentially consequential distinctions. Indeed, this example suggests that the very term 'good' can fall outside the commonplace social psychological focus on individual preferences. Some of the business that participants can do with the distinction between 'liked' and 'good' will be discussed shortly. 


\section{Variability of Attitude Expression}

So far I have indicated some of the general features of a discursive social psychological approach to evaluation. As discursive social psychology developed, one of the main lines of criticism of traditional work on attitudes revolved around the identification of variability in the use of evaluative expressions (Billig, 1989; Potter and Wetherell, 1987; Wetherell et al, 1987). At its simplest the argument is as follows.

When evaluative expressions are looked at carefully and systematically variability has been found that is theoretically consequential. The same individual can be found offering different evaluations on different occasions, or even during different parts of a single conversation. Generally such variability has either been missed or suppressed or ignored when more traditional techniques of attitude measurement are used. Such variability is an embarrassment to theories which hope to explain behaviour as a product of consistent, underlying, cognitively represented evaluative positions. In contrast, variability of this kind is expected within discursive social psychology, which has studied the way evaluations are flexibly constructed to mesh with specific ongoing practices. Variation is expected as people perform different actions with their talk; for example, as they respond to assessments, align themselves with friends and differentiate themselves from enemies, and as they construct locally coherent versions of the social and moral world.

What is being suggested about variability can be illustrated by recent and simple study by Burningham (1995). She examined accounts produced in the context of a 'social impact assessment' designed to assess people's attitudes to a proposed road scheme. She demonstrated variability in the interview talk of single individuals. For example, one individual produced negative evaluations of road schemes because they destroy the countryside but elsewhere in the interview produced positive evaluations of road schemes 
because they can be produced without damaging the environment. Without going into the detail of Burningham's study, its argument is that variations of this kind are produced because people are performing a different tasks while talking about environmental damage, and these tasks are best performed through producing accounts involving differing evaluations.

Note that this account is not in terms of impression management. The suggestion is not that people have an actual attitude, whose expression they modify in accordance with social constraints of various kinds. Rather, the argument is that people engage in a family of evaluative practices. Some of these may implicate, for participants, issues of face; others may implicate, again for participants, issues of consistency. Yet neither theories of impression management nor traditional attitude theory make adequate sense of the organization of those practices in different situations.

There are now a range of studies which reveal variability in a wide range of different settings including the talk and letters of research scientists (Gilbert and Mulkay, 1984; McKinlay and Potter, 1987; Mulkay and Gilbert, 1981, 1982, 1983, 1985; Potter, 1984, 1987, 1988); talk about race and racism (Potter and Wetherell, 1988, 1989, 1995; McCreanor, 1989; Nairn and McCreanor, 1990, 1991; Shi-xu, 1996; Wetherell and Potter, 1992); accounts of government communicators (te Molder, 1996); talk about gender, careers and inequality (Campbell, 1995; Gill, 1991, 1993; Marshall and Wetherell, 1989; Wetherell et al., 1987); talk about the Royal Family (Billig, 1991, 1992); claims in parliamentary discourse and newspaper articles related to a political dispute (Edwards and Potter, 1992a,b; Potter and Edwards, 1990, 1994); talk in work settings such as education and medicine (Billig et al., 1988); talk about health and dieting (Lupton and Chapman, 1995; Wetherell, forthcoming) and social work (Roffe, 1996). The majority of these studies do not take 'attitude variability' as their topic as, for the most part, discursive social psychologists have avoided presupposing a notion of attitudes and related theoretical apparatus; however, they are all studies of the 
construction of talk and texts which either includes variability in direct assessments or in talk closely related to the production of assessments.

It might be objected that this research on variability is inadequate, particularly given the huge investment in time and effort in traditional attitude studies, because it does not provide reliable and quantified measures of variability. The response to this would be that the aim of this research has not been primarily to assess the extent of variability but to document its existence as a pathway to further analysis.

Moreover, variability is precisely the kind of phenomena that can be obscured by the kinds of counting and coding prevalent in traditional attitude work which can easily overestimate homogeneity at the expense of variability (see Potter \& Wetherell, 1987; Potter \& Litton, 1995). Such homogenizing is a consequence of using coding practices that take instances which may be superficially similar, but may display a range of differences that discursive social psychologists would treat as interestingly variable, and placing them in the same category. Without access to the original materials the reader is faced only with counts which appear homogeneous. As I noted above, one of the methodological virtues of some discourse research is the presentation of extended passages of the original materials that allow the analytic interpretations to be assessed by the reader. (It could be argued that inter-rater reliability would eliminate this problem — however, this just pushes the problem back to the training of raters; if both are inattentive to phenomena that discourse researchers would expect to be consequential they will achieve high reliability scores regardless.)

Recently some studies have attempted to include measures of 'attitude variability' along with other variables (e.g. Norman and Smith, 1995; Prislin, 1996; Sparks et al., 1992). These studies can illustrate the sorts of reservations that discursive social psychologist have with the way variability is operationalized. 
Take a study of attitudes to exercise by Norman and Smith (1995). They measure variability by items such as: 'My feelings about taking exercise are sometimes favourable and sometimes unfavourable'. There are a number of difficulties with this approach. First, it assumes that variability is 'attitude variability'. That is, it assumes that people have some inner position — the attitude — but that it varies over time. Discursive social psychologists have not started with the assumption that people must have consistent personally held evaluations that are carried from one context to another. The variability they are interested in is not a temporal fluctuation like changes in the weather, cloudy for a few days and then sun. Rather it is a discrete and specific variation tied to the nature of the action that is being performed. The point again is that evaluations are not treated as something that are carried around ready made by participants but are worked up in a way that is suitable for what is being done. In discursive social psychology attitudes are performed rather than preformed.

The second problem is that it treats people as 'honest souls' who can and will provide comprehensive, honest and reliable information about their actions and mental states. The irony here, of course, is that it is traditional social psychologists who criticised the 'honest souls doctrine' of new social psychological approaches such as Harré's ethogenics in the 1970s. The apparatus of traditional attitude measurement relies much more centrally on people being honest souls than its discursive alternative does.

The third problem is closely related to the second. For all intents and purposes it treats as irrelevant the fact that 'responding' to an attitude scale is an activity. What people may be doing with their words in these settings is not made a topic of study; instead the words are treated as a pathway to the speaker's inner world. For example, it is possible to imagine that people might find it a much more accountable matter to answer that attitudes are highly variable for some topics — voting intentions, say — rather than others — the choice of a brand of biscuits perhaps. Indeed, it is possible to imagine searching a corpus of 
conversations for situations where people describe their views as changed or changing, and to consider the kinds of interactions that such claims are a part of. This would start to consider what people are doing with such avowals rather than treating them as transparent pathways to mental facts.

One discursive study which has focused in detail on the expression of strong views was conducted by Billig (1989). Billig's general suggestion (e.g. 1988a,b) was that evaluations are rhetorical. That is, people produce evaluations where there is at least the possibility of argument, and expressing an evaluation for something is often simultaneously the expression of an evaluation against something else. People tend not to argue the virtues of gravitational force, as it is taken to be something that simply exists; however, they argue the virtues of a federal Europe, and in doing so may be treated as arguing against particular forms of nationalism (Billig, 1995).

This suggests that it will be fruitful to study evaluations in their home environment of argument. And where Billig does this, with the case study of an individual who professes elaborately and frequently that they have strong views on the British Royal Family, his study documented considerable variation in those views. Indeed, Billig concludes:

The metaphor of 'holding' strong views is somewhat misleading, if it implies the possession of a pre-formed and unchanging mental object. Instead the business of holding strong views is an unfinished business, for the discourse of views involves creating new elaborations and qualifications. As their views are held so they are formulated. (1991, p. 191).

The 'views' in this study are modified and finessed in the course of arguments with different people and as new rhetorical oppositions were built up.

In the end, the identification of variability in itself does no more than ask some searching questions about the workings of attitude theories. Variability can always be 
dismissed as the consequence of various 'social influences' on attitude expression or as a product of examining situations where the attitude in question has not been made salient (although too many arguments of this kind can turn into an ad hoc list of modifications to sustain the existence of the object in the face of counter evidence). The more important move in discursive social psychology is to use this variability as a resource for analysing the actions that people perform and the resources that they draw on to perform those actions.

\section{Organizations of evaluation}

The previous section highlights the negative challenge that discursive social psychology presents to traditional attitude theory. In this section I will start to illustrate the more positive contribution that can be made to a social psychology of evaluation. It will focus particularly on two areas of study where conversation analysts have highlighted features of interaction involving evaluation that have been passed over by attitude theorists. (For a useful introduction to conversation analysis, see Nofsinger, 1991; for a discussion of its relation to discursive social psychology, see Potter, 1996c).

The first of these areas of study concentrates on the manner through which evaluations are made in mundane conversation. In a deceptively simple study, Pomerantz (1984) took a large number of careful transcripts of everyday conversation and went through them looking for places where a speaker made an evaluative assessment of something; that is, described something as good or bad. She was not concerned with traditional attitude issues - i.e. did this assessment reflect a stable underlying disposition?; would it correlate with something they said or did in another setting? - rather, she was interested in how assessments are part of interaction, and in particular in what happened immediately after one speaker had made an assessment. 
Pomerantz found that there was a very strong regularity in what happens after assessments. Overwhelmingly after one person has made an assessment the person they are speaking to follows it with one of their own.

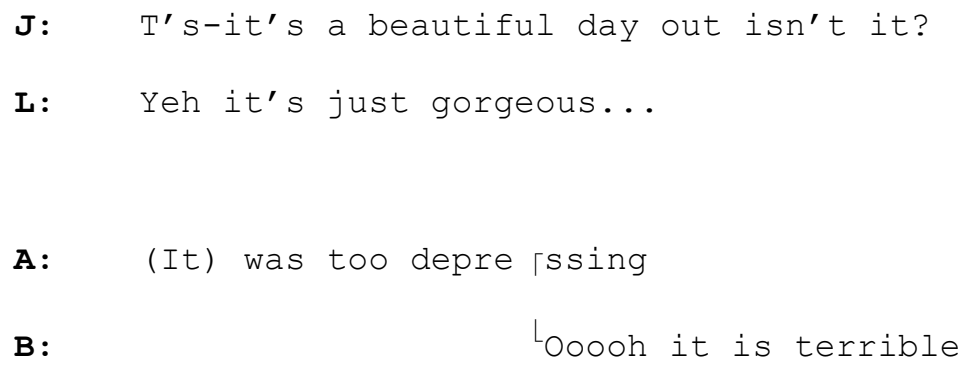

The strength of the pattern is shown by the fact that people can elicit a view from another person simply by offering a view of their own, and also by the fact that silence after an assessment is often interpreted as a disagreement.

Pomerantz further noted some subtle, but again very regular differences between the patterning of second speaker's assessment according to whether they are offering agreement or disagreement. The two examples above are typical agreements. The second assessment follows with a minimum of delay, the agreement is made clear early in the turn, and the agreement is 'upgraded'. Thus, in the first case above, there is no delay before L starts to speak, the turn is started with the agreement ('Yeah') and the assessment is upgraded ('beautiful' is strengthened to 'just gorgeous').

Disagreeing assessments follow a rather different pattern. There is typically some delay before the second turn, the disagreeing component is softened or qualified, and the disagreement appears later in the turn. Indeed, disagreements are often prefaced by agreements. The following examples illustrate some of these features.

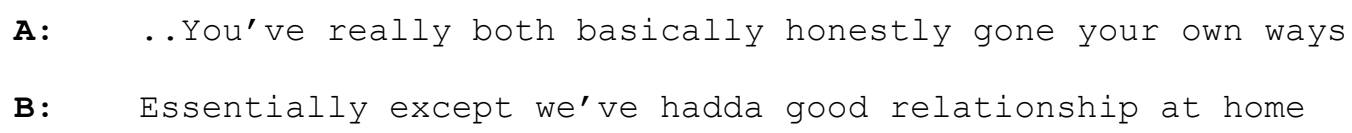




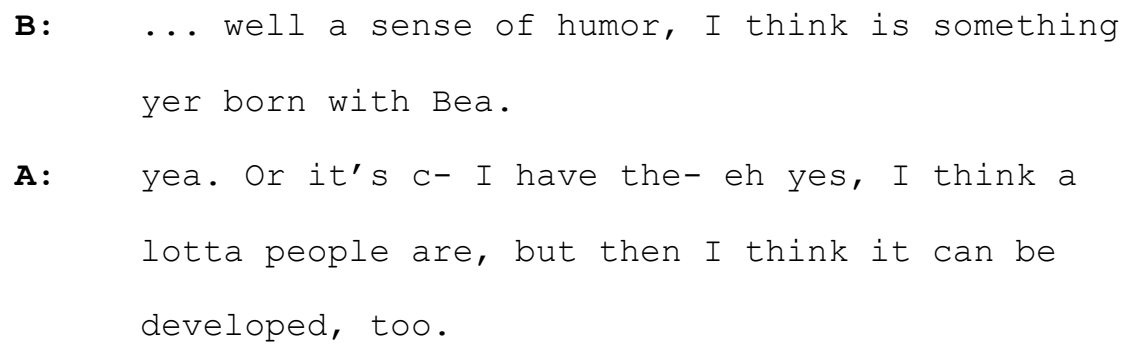

(All from Pomerantz, 1984; transcription slightly simplified)

Pomerantz (1978) extended this line of research to identify some of the regular features of compliments and self-deprecations. In the case of self-deprecations the standard patterning is reversed, with disagreements being performed immediately and with upgrade, while agreements are delayed and softened. Compliments are more complicated still as the standard pattern of immediate agreement conflicts with social norms against explicit expressions of self praise (boasting). Pomerantz identifies a range of different ways in which people manage these conflicting demands, including downgrading the praise, reassigning it to another person or object, or returning it to the speaker.

The important point, then, is that Pomerantz's research shows in the case of simple everyday assessments that they have a regular organization which depends on their specific position in an interaction. This influences both the strength of the evaluative expression and its organization. Now it could be argued that these are merely trivial evaluations made in mundane talk and that the apparatus of attitude measurement with its Likert and Osgood scales bypasses this to something more solid. In contrast to this, conversation analysts have argued that such mundane conversation is the home environment of many features of interaction. Participants learn about the nature and role of evaluation in these settings, and this knowledge is a backdrop to, and gives sense to, their actions when faced with, say, an Osgood semantic differential scale. Indeed, Myers (1996) has developed the implications of this work for reinterpreting what takes place in focus groups (see also Suchman and Jordan, 
1990 on survey research and Antaki and Rapley, 1996 on quality of life measures). Far from being a trivial irrelevance, then, these sorts of everyday taken-for-granted practices of evaluation may be the foundation of more technical social science practices of evaluation.

The foundational role of studies of evaluations in everyday settings can be illustrated by showing the way they have helped throw light on what at first sight seems a rather separate and conventionally more significant topic: the interaction of an orator with an audience. The conversation analytic approach to oratory has been very different from that of traditional social psychology. They have shown that political oratory is in important respects like a conversation between a speaker and audience. Pomerantz showed that in everyday conversation when a speaker makes an assessment the person being talked to generally provides their own assessment. Now at a political rally, or the hall of a political conference, the audience cannot simply talk back; they cannot say 'yes, the Labour policy on employment is disastrous' or 'absolutely, we have got law and order cracked'. However, there are conventional and effective ways of producing evaluations in these contexts: people applaud, cheer, boo or, more rarely, heckle.

Researchers into oratory have found that applause regularly follows parts of speeches where the speaker is making an assessment; a claim of the form 'our party is brilliant', 'our policy is great', 'their party is awful' and so on (usually more subtly). Just as in an everyday conversation, then, when the speaker produces an assessment the audience will generally respond to it with their own assessment. However, the successful elicitation of clapping does not depend simply on making assessments in the course of speaking. Another feature of oratory is like everyday talk; and that is that people make extremely finely tuned predictions about the completion of prior turns. There is often no perceptible gap at all between one speaker finishing their turn of talk and the next speaker starting. This shows that people are not responding to turn endings, but are predicting when turns will end so they can synchronise 
their own contribution (Levinson, 1983; Sacks et al., 1974). This phenomenon of predicting completions is particularly important in public speaking where the close co-ordination of possibly several thousand people is required in a setting where many of them may have a poor view of the speaker and degraded sound quality may mean they miss many of the subtleties of speech production.

Studies of oratory suggest this difficult problem of co-ordination is solved by the use of a range of rhetorical formats (Atkinson, 1984a,b; Heritage and Greatbatch, 1986). These are ways of constructing talk so that completions can be easily predicted. For example, in a study of almost the entire set of speeches from the 1981 party conferences in Britain, Heritage and Greatbatch (1986) identify six basic rhetorical formats: contrasts, lists, puzzle-solutions, headline-punchline, position taking and pursuit. All these formats provide information for the audience concerning precisely when applause is due. For example, with contrast structures which are the most common format — the audience is readied to applaud in good time by the onset of the first part and are thus well prepared by the completion of the second. The following example from illustrates the standard pattern:

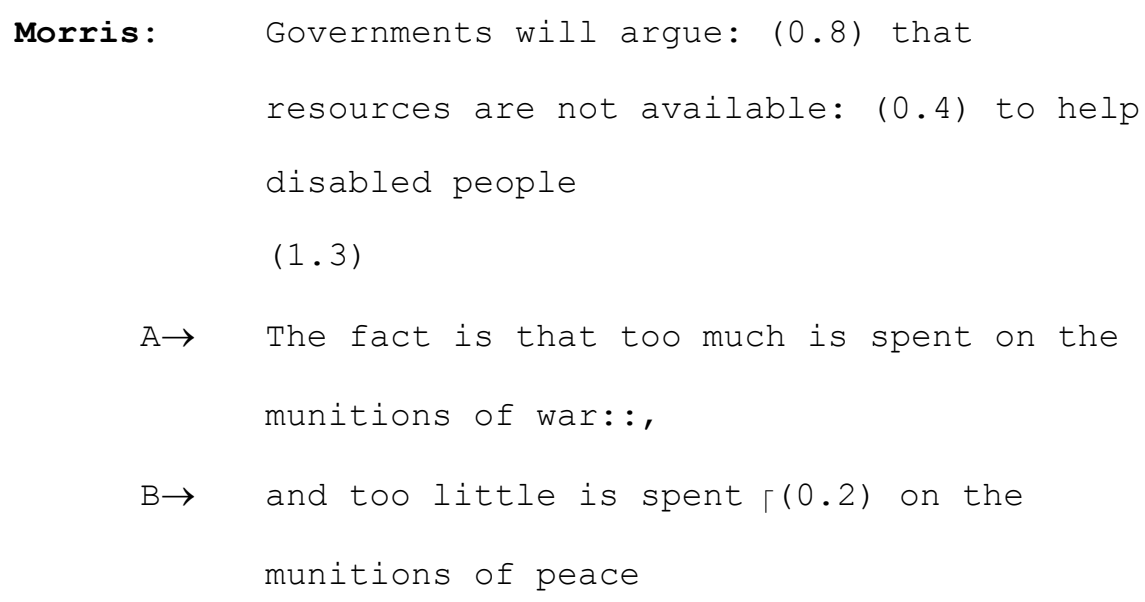

Audience

LApplause (9.2 seconds)

(Heritage and Greatbatch, 1986, pp. 123) 
In their study, Heritage and Greatbatch found that two thirds of 1,588 sets of applause followed one or more of these rhetorical formats. Put another way, if an evaluative claim is couched in one of these rhetorical formats it is at least twice as likely to get applause and in some situations may be nearly ten times as likely. Of course that is not all there is to it either. Speakers can use contrasts or lists in a confused way, downgrading their effectiveness, or they can enhance their effectiveness by combining formats or co-ordinating spoken oratory with suitable gestures (Atkinson, 1984a; Clayman, 1993; Grady and Potter, 1985).

The general point is that is that the study of assessments in mundane conversation has started to provide insights in areas where social psychologists have traditionally been concerned with a range of communicator 'variables' such as attractiveness, credibility, similarity and status (Hovland et al., 1953; see Eagly \& Chaiken, 1993 for recent discussion). It has moved the focus away from events and processes in the heads of individuals and onto the sorts of practices that go on when people are using evaluations in social contexts. Pomerantz's study allows us to compare making an assessment with other actions such as giving an invitation, say, or making an accusation. Heritage and Greatbatch's study shows the way that assessments are a central part of political oratory, and that their 'success' depends on subtle discursive organizations.

\section{Evaluative Practices and Ideological Discourse}

Another way in which discursive social psychologists have moved away from traditional notions of attitudes is that they have started to analyse the production of assessments as part of broader activities which are dependent on a range of symbolic resources, some discrete and some broadly patterned. In some ways the argument is similar to that made by social representations researchers who have downgraded the importance of 
attitudes in favour of understanding the socially shared representations that people hold which underpin their attitudes (Moscovici, 1984). In the case of discursive social psychologists, the concern has been with the interpretative repertoires and rhetorical commonplaces that are used to make particular evaluations coherent and accountable. This line of work is most developed in three book length studies: Billig (1992) on talk about the Royal Family, Billig et al. (1988) on the organization of everyday ideology, and Wetherell and Potter (1992) on discourse and racism; however, it is easiest to introduce the work by way of a relatively simple and small scale early study (Wetherell et al., 1987).

Wetherell et al. (1987) focused on men's talk about women's career opportunities in open ended interviews. It did not attempt to ask these participants what their attitude was to women's' career advancement, rather the interviews gave them the opportunity to provide extended descriptions, explanations and judgements as they dealt with a range of questions and comments from the interviewer. Close analysis of the interviews found a regular pattern. On the one hand, the men supported the principle of women's career opportunities and attacked discrimination based on gender. On the other hand, the men offered a wide range of practical reasons for the failure of women to reach full employment equality, including references to such concerns as childcare, tradition, and emotional unsuitability to stressful work. Note the significance of this pattern. These men have the ability to affirm both support for women's' employment equality (in principle) and support for continued inequality (because of important practical concerns). They can be what the authors' dubbed 'unequal egalitarians' who support a status quo of inequality while displaying themselves as non-sexist through their abstract support of egalitarian principles.

It is important to be clear about the implications of this study. In the first case, it suggests that using a traditional technique such as an attitude questionnaire, combined with attitude theory's notion of unitary individual preferences, will not be adequate to understand 
how these people construct evaluations about gender and employment. In a sense, they have contradictory views, positive and negative. But this is why an attitude approach is inadequate to capture what is going on here.

The second point to emphasise is that this interview talk may well underestimate the variation in such evaluations and the way in which they are used in practical contexts. For example, Gill's (1993) study of radio controllers' accounts for the low representation of female DJs repeats the general pattern of support for principles of equality combined with practical reasons for failures to appoint more women. However, the specifics of the accounts are rather different as the controllers are describing and justifying their own recruiting practice. It is notable that they construct accounts to present the lack of recruitment as a product of external factors rather than their own desires; for example, few women apply, or listeners do not like women's 'shrill' voices.

An attitude researcher might counter at this point that these studies merely document the sorts of mismatch between 'attitudes' and 'behaviour' that result from the range of social constraints on 'behaviour' that interfere with its smooth connection to 'attitudes'. However, this would be to miss precisely what discursive social psychologists have emphasised, which is the way talk is orientated to action. For in presenting their views as egalitarian, but their practice as constrained, they can counter potential criticisms from a liberal seeming and female social researcher while explaining and justifying an unequal practice. Traditional attitude measurement and theory pays almost no attention to what is done by attitude talk, let alone what is done by different descriptions of behaviour.

Where traditional attitude theory has looked to the intrapsychic world of cognitive psychology for its explanations, discourse research has looked instead to conversational pragmatics, and more broadly social and ideological conflicts. This line of thinking is developed in Billig et al's (1988) work on 'ideological dilemmas'. Their argument is that the 
common sense of everyday talking and arguing is organized around dilemmas which are often ideological in the sense that they relate to broader societal concerns with authority, legitimation and social organization. For example, they discuss the way classroom teaching is organized around a dilemma between student self discovery and teacher control over learning outcomes (for a more developed study of education in this way, see Edwards and Mercer, 1987). The important point they make is that these dilemmas are not a problem that has to be resolved, rather their tensions structure social settings and provide contradictory sets of resources that sustain current practices. In the case of Gill's (1993) radio controllers, for example, the contradictions between egalitarian values and discriminatory practice are not a problem for the stability of the institution; quite the reverse, they can help sustain its current status quo.

At this point it might seem that a monopolar attitude theory has been placed by a bipolar theory of dilemmas. I will take one more example to show the possibilities in a more complex situation. One of the studies reported in Wetherell and Potter (1992) considered Aotearoa (New Zealand) white majority group members' accounts of controversial topics related to ethnic relations: land rights, Maori language teaching, and affirmative action programmes. Across the corpus of 81 interviewees, along with materials from newspaper articles and records of parliamentary debates, a small number of what Billig (1987) calls 'rhetorical commonplaces' were identified. These were brief arguments, often using the same phrases which were generally treated as clinching, or as invoking principles that were beyond question. Some examples are:

Nobody should be compelled.

Everyone should be treated equally.

You cannot turn the clock backwards.

Present generations cannot be blamed for the mistakes of past generations. Injustices should be righted. 
(from Wetherell and Potter, 1992, p. 177)

Note that these commonplaces do not fall neatly into categories as values, or empirical generalizations or ideological observations. In most cases they could be built as features of morality, or politics, or treated as empirical according to their use. This again illustrates the emic nature of discursive social psychology — the aim is not to impose an abstract coherence onto participants' discourse by treating it as generated by unitary individual attitudes or singular political ideologies. Instead, the aim is to appreciate the fragmentary organization of political evaluations, and to show that what might appear on the face of it vague or ambiguous actually has a fine organization.

One of the immediately obvious features of this list of commonplaces is that it does not fit easily together: righting injustices can conflict with not turning the clock backwards; and more generally some of the commonplaces invoke individual rights while others stress practical considerations. Following Billig et al, Wetherell and Potter argued that the contradictory nature of this discourse permits a very wide rhetorical flexibility which is shown when the participants argued against the courts dealing with Maori land disputes or schools teaching Maori to Pakeha (white) pupils. In broader terms, Wetherell and Potter argued that to understand the organization of racism and ethnic relations in New Zealand notions of prejudiced attitudes were not adequate. Instead it was necessary to understand both how these innocuous and broadly liberal argumentative resources were used in practice to undermine political changes promoting the position of Maori and Polynesian groups, and how they are broad resources that have been established in the specific history of New Zealand culture and its political and social discourses. In general, the work described in this section has moved away from the study of individual preferences to attempting to understand how evaluations are bound up with practical and ideological questions. 


\section{5. $\quad$ Facts and Neutrality}

One of the notable features of attitude research is that there is a negligible amount of work on neutrality or not holding an attitudes. Moreover, while researchers have focused on evaluations, description hardly figures as a topic. People who tick 'don't know' on attitude or opinion questionnaires are typically treated as uninteresting or a methodological problem to be managed. However, recent work in discursive social psychology has focused specifically on descriptions and factual accounts (Edwards, 1994, 1995; Edwards and Potter, 1993; Potter, 1995, 1996b; Potter and Edwards, 1990; Potter and Wetherell, 1988; Potter et al., 1993) and conversation analysts have explored the way neutrality is managed interactionally in particular settings (Clayman, 1992; Heritage and Greatbatch, 1991). I will discuss the conversation analytic work first.

Heritage and Greatbatch (1991) studied interaction in broadcast news interviews. They found that, in contrast to everyday talk, the interviewees did not treat the interviewers as accountable for views and claims expressed in questions by the interviewer. Instead they treated them as animating the views of others or as producing abstract points for the sake of clarifying issues. It is rare for news interviewees to treat interviewers as expressing their own attitudes, and when this does happen it can lead to tricky interactional problems (Heritage \& Greatbatch, 1991; Nofsinger, 1991; Potter, 1996b). In a complementary study, Clayman (1992) studied a specific technique that news interviewers used to construct their own neutrality. Typically when they produce questions involving a contentious description of some state of affairs they constructed it as a quote from a particular speaker, or they may treat it as what people in general have claimed. By doing this they construct their discourse as not motivated by their own attitudes or biases but merely reporting what other relevant parties have said. They are constructing themselves as without attitude. 
It is important to stress that Clayman and Heritage and Greatbatch are not treating neutrality as a technical notion, but are treating it as an issue for participants. To claim that news interviewers are displaying neutrality through their discourse practices is not to claim that they are actually neutral according to some cognitive, political or sociological criterion. This move to consider the way stake, attitude and neutrality are managed by participants in practical settings is mirrored by work in discursive social psychology.

Edwards and Potter (1992a, 1993; Potter et al, 1993) have argued that when people perform sensitive actions (such as making requests, turning down invitations, criticising others) they often do so by way of descriptions. Take the following simple example discussed in detail by Wooffitt (1992):

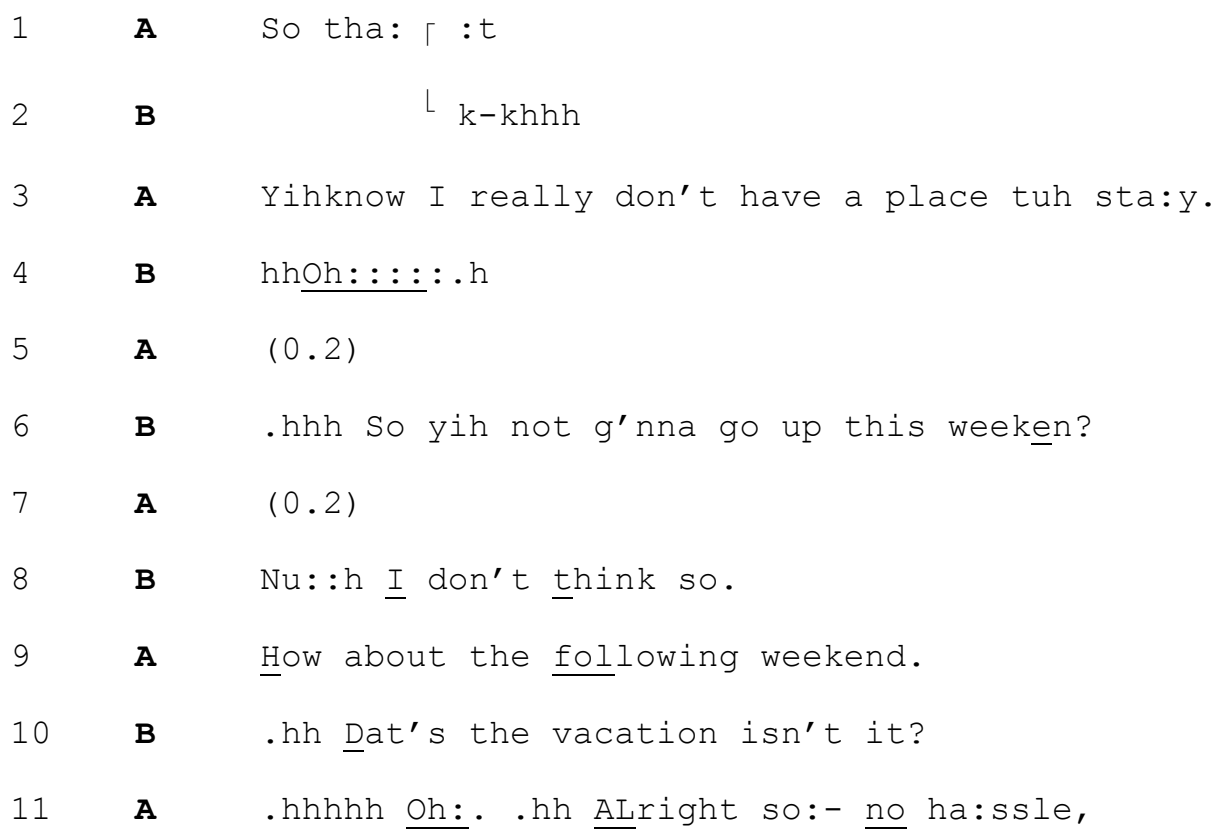

Without going into details here we can note the way in line $10 \mathrm{~B}$ turns down A's invitation. He registers inability to go on the trip without an explicit rejection, but by a (contrastive) description 'dat's the vacation'. Drew (1984) has claimed such inability accounts are pervasive when performing actions such as refusals, disagreements, and rejections. The point to emphasise for the current discussion is what actions and accounts of this kind are not 
doing, which is making reference to personal preferences: desires, wishes, attitudes. When was the last time you heard an invitation turned down by the speaker saying 'I won't come' because 'I don't feel like it', or 'I don't like you'? These are not activities where the language of attitudes is generally considered appropriate.

This phenomenon is not restricted to what might be thought of as rather trivial practices such as invitations and refusals. The same pattern can be seen in talk about race and ethnic relations. Potter and Wetherell (1988; see also Wetherell and Potter, 1992) performed a detailed analysis of a single case where the interviewee was making a range of derogatory and racist claims about members of minority groups. In the following extract the interviewee has been discussing the topic of crime.

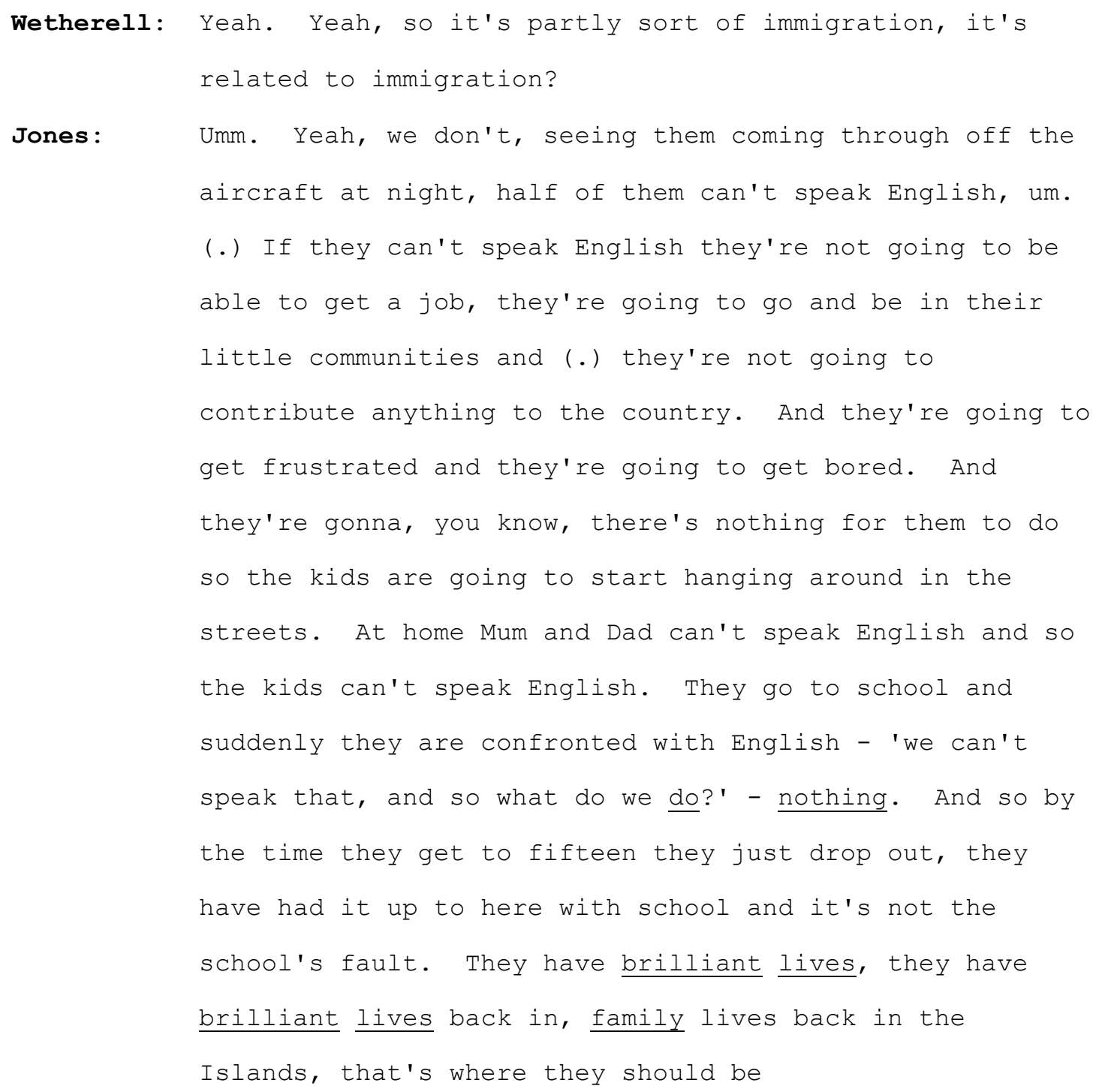


The feature of this mature I want to emphasise here is that the speaker is not constructing his talk in the language of attitudes. That is, he is not talking of his preferences for particular minority groups; indeed, he is not giving any direct formulations of his own psychological states. Instead, he is constructing versions of minority groups and their characteristics and actions from which evaluations could be inferred. Put simply, the negativity is constructed as lying out there in the world rather than being a feature of his own psychology. The upshot of this type of construction is that the speaker should not be held accountable for holding negative attitudes, rather the minority groups members should be held accountable for their problematic behaviour.

The upshot of this line of work is that situations where people are constructing descriptions are just as interesting, just as significant in social psychological terms, as those in which people are espousing attitudes. Moreover, it is brings to the fore a set of concerns and questions which have not be tackled by social psychologists up to now. For example, if descriptions are as important as this work suggests for performing sensitive actions then the study of how descriptions are constructed so as to perform actions becomes important, as does the question of how descriptions are constructed as factual and independent of the speaker. Note, for example, the way independence from the speaker is constructed and value is made a feature of the world rather than the speaker in the following extract:

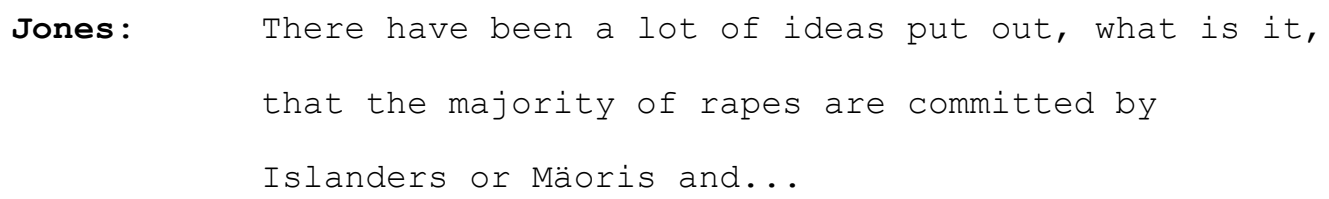

Here the extremely negative description about rape is produced as an 'idea put out' — that is, not an idea the speaker himself has produced. Furthermore, the phrase 'what is it' acts a display of searching for a formulation that is not quite remembered. It works him up as not the kind of (racist, hostile) person who actively notes down negative items about minority 
groups, let alone produces them himself. The topics of action via description and fact construction are explored at length in Potter (1996b).

\section{Respecification of attitude concepts}

In this final section I will briefly review some of the theoretical notions that have been important in attitude research: function, consistency, vested interest. The aim is to show how these concepts can be translated from a cognitive to a discursive framework.

Function. The traditional view of function in attitude research focuses on the role holding an attitude might have for an individual. Probably the best known scheme (Katz, 1960) has one function for each of the available theoretical systems for the time: the utilitarian function of an attitude is to maximise rewards (behaviourist); the ego-defensive function is to protect the self from unwelcome inner impulses (psychoanalytic); the knowledge function organizes coherence (cognitive); the value-expressive function expresses core values (humanistic). Whether these functions can be coherently specified and researched is outside the scope of this current discussion. The important point to emphasise here is that discursive social psychology is, at least arguably, working with a much more straightforward notion of function when it takes as its topic evaluative practices; that is, what people are doing by making evaluations (or displaying a lack of evaluation) in particular settings.

Some of the confusions that can arise with the traditional view of function can be seen in research using this view. Take Maio and Olson (1994). They studied attitude functions in relation to 'attitude-value-behaviour relations' in the context of student non-smoking areas. Attitude functions were measured using Shavit's (1990) 'thought-coding scheme', which the authors describe as a 'method for directly measuring attitude function'. Participants were asked to 'list all of their thoughts that were relevant to' attending a dance to highlight a 
campaign for non-smoking areas. Then these 'thoughts' were coded as either valueexpressive or utilitarian. The problem from a discursive perspective is not just with the notion that thoughts are the kinds of objects that can be simply listed in linguistic form like the print out from a wordprocessor, although this is certainly a major problem, it is with the untheorized manner in which statements are assigned to a particular function. For example, they give as a paradigm example of a value-expressive thought:

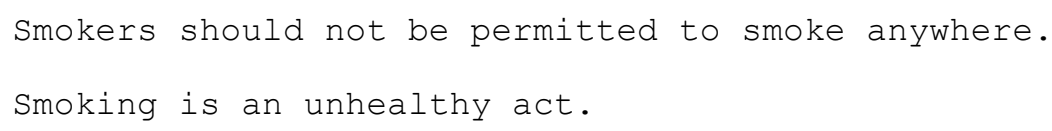

The difficulty highlighted by the sort of discourse work on evaluative practices and ideological dilemmas discussed above is that isolated phrases of this kind can be used in a wide range of different ways. It is not hard to imagine 'smoking is an unhealthy act' used as the account element in a practical, utilitarian request for a neighbour to stop smoking. For discourse workers, function needs to be identified through studies of talk in settings rather than through assigning decontextualized materials to categories by analytic fiat.

Consistency. Consistency has been one of the most fundamental theoretical notions in attitude work ranging from Heider's balance theory, Festinger's cognitive dissonance, to more recent social cognition approaches (see Fiske and Taylor, 1991). Consistency is also treated as important in discursive work. However, there is a major difference, which is that in discursive social psychology consistency is not treated as a logical relation than can be assessed by the researcher. Instead, it is treated as a participants' concern. This highlights two features that have not been traditionally emphasised.

First, consistency can be managed across settings; studies of evaluative talk show the way different explanatory and evaluative repertories can be drawn on in different passages of talk, or in different settings (Billig, 1991; Gilbert and Mulkay, 1984; Wetherell and Potter, 1992). Second, and more significantly, consistency is not something that is merely, factually 
the case or not. Detailed studies of discourse show the way consistency can be constructed and undermined using a range of different rhetorical devices (Potter, 1996b). Again, the logic of this is to start from a study of the way consistency is managed in practice rather than making prior analytic judgements which may be at odds with some or all participants and may reflect a range of untheorized prejudices.

Vested interest. Some researchers have recently emphasised the importance of "vested interest' as having an important role in mediating the consistency of attitudes and behaviour (e.g. Crano and Prislin, 1995). The argument is that behaviour is likely to follow attitudes where there is a vested interest, but not where such an interest is absent. There are already discourse analytic cautions on the notions of 'attitude' and 'behaviour'. 'Vested interest' has been a topic in discourse research. However, just as with consistency, the focus has been on how vested interest is constructed and managed in particular accounts and settings. For example, several studies have emphasised the way the vested interest of others is may be built up as a procedure for discounting their claims or actions (Edwards and Potter, 1992a, 1993; Potter et al., 1993) and Potter (1996b) has argued that vested interest of one kind or another is pervasively attended to when descriptions are constructed as factual. Traditional research on vested interest and attitudes has systematically underplayed the constructive and rhetorical work done with vested interests in natural settings through using a range of methodological techniques. For example, Crano and Prislin (1995) use vignettes where vested interest is predefined rather than being something that has to be worked up, played down, and made relevant or irrelevant.

Emotion. It is worth ending with a brief comment on emotion, as it has been a commonplace feature of a range of attitude theories to treat attitudes as having a cognitive and an affective component. In Zanna and Rempel's (1988) influential definition, for example, attitudes are evaluative categorizations depending on information about cognition, 
past behaviour and emotion. Indeed, emotions have often been treated as a background motivator, something essentially separate from, and underlying, the rational information processing world of cognition. Without going into detail here, discursive social psychologists have recently been developing a rather different approach which considers the way emotion displays and emotion talk figure in interaction (Buttny, 1993; Edwards, 1997, forthcoming; Harré, 1986).

For example, Edwards explores the some of the roles of emotion descriptions in relationship counselling sessions, noting how they can play important parts in narratives that construct moral identities for the parties and warrant particular outcomes. He emphasises in particular the importance of the multifaceted nature of emotion talk, and the ways it can be rhetorically worked up as rational vs. irrational, cognitively grounded vs. cognitively consequential, event driven vs. dispositional, or even cognitive vs. emotional. It is this very flexibility that allows it to be a powerful resource in interaction. In terms of a discursive social psychology of evaluation, the linking of attitudes and emotions makes sense when suitably translated into a study of evaluative practices where displaying strong views or opinions may well involve psychological constructions that would previously have fallen into psychology's rather loosely theorized category of emotion.

\section{CONCLUSIONS}

The aim of this paper has been to introduce discursive social psychology by discussing how it has respecified, and how it could further respecify, the problematics of attitude research. The basic move is away from an in-the-head notion that has people carrying around the mental equivalent of ready filled-in Likert scales for the attitude objects in their lives, and towards a notion of heterogeneous evaluative practices which are used in different settings for 
different purposes. Along side this respecification comes an emphasis on the symbolic systems (categories, commonplaces, interpretative repertoires) which are resources for constructing evaluations, and the way evaluations are rhetorically worked up by participants as located within individuals in some settings while being separated from individuals and made features of the world in others. 


\section{APPENDIX: BRIEF TRANSCRIPTION NOTATION}

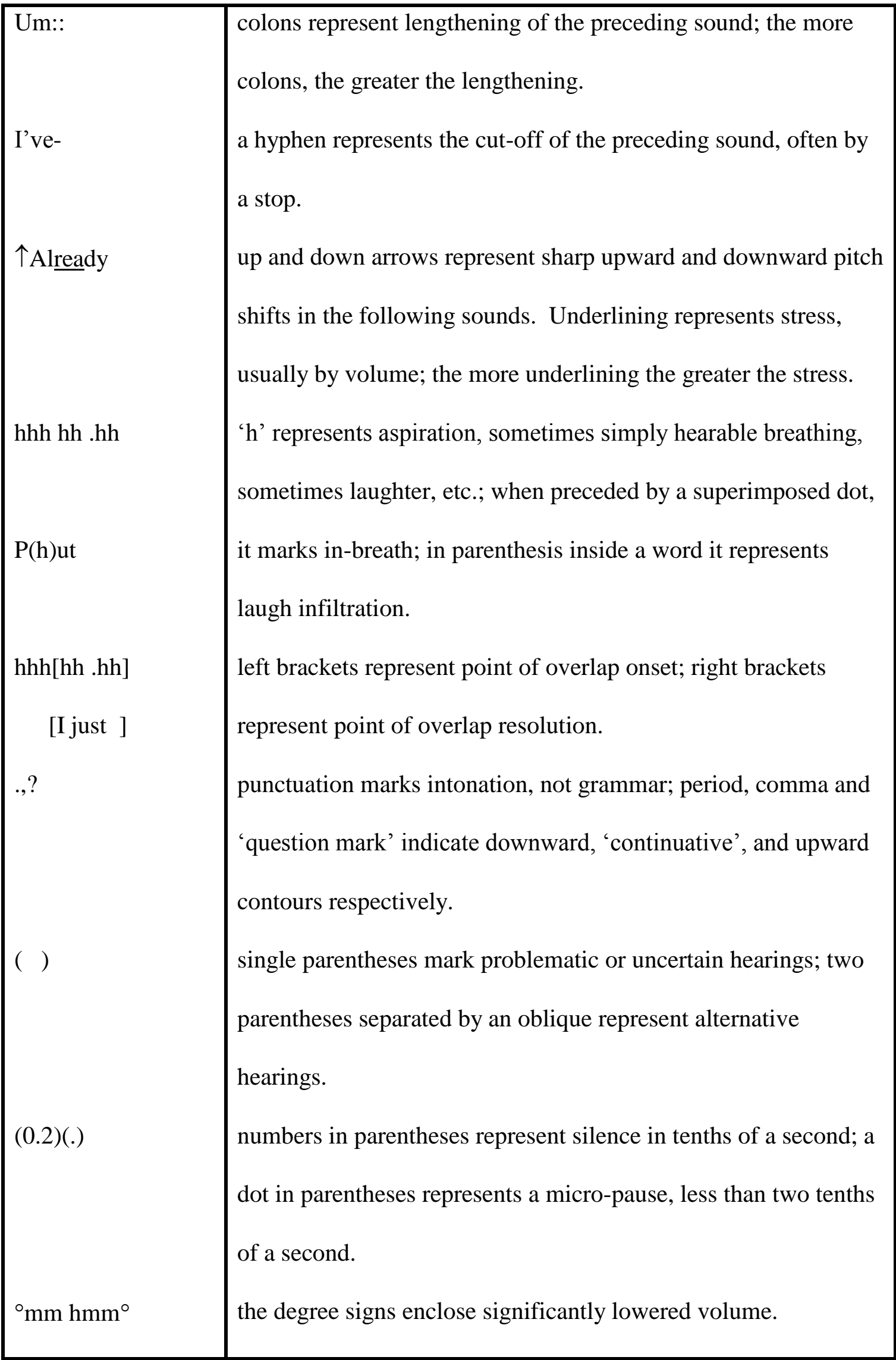


(slightly modified from Schegloff, 1997, pp. 184-5) 


\section{REFERENCES}

Antaki, C. (1994). Explaining and arguing: The social organization of accounts. London and Beverly Hills, CA: Sage.

Antaki, C. \& Rapley, M. (1996). 'Quality of life' talk: The liberal paradox of psychological testing. Discourse and Society, 7, 293-316.

Ashmore, M. (1989). The reflexive thesis: Wrighting sociology of scientific knowledge. Chicago: University of Chicago Press.

Atkinson, J.M. \& Heritage, J.C. (Eds.) (1984). Structures of social action: Studies in conversation analysis. Cambridge: Cambridge University Press.

Atkinson, J.M. (1984a). Our master's voices: The language and body language of politics. London: Methuen.

Atkinson, J.M. (1984b). Public speaking and audience responses: Some techniques for inviting applause. In J.M. Atkinson \& J.C. Heritage (Eds.), Structures of social action: Studies in conversation analysis (pp. 370-409). Cambridge: Cambridge University Press.

Azjen, I. (1988) Attitudes, Personality and Behaviour. Buckingham; Open University Press.

Berger, I.E. (1992) The nature of attitude accessibility and attitude confidence: A triangulated experiment, Journal of Consumer Psychology, 1, 103-23.

Billig, M. (1985). Prejudice, categorization and particularization: From a perceptual to a rhetorical approach. European Journal of Social Psychology, 15, 79-103.

Billig, M. (1987). Arguing and thinking: A rhetorical approach to social psychology. Cambridge: Cambridge University Press.

Billig, M. (1988a). The notion of prejudice: Some rhetorical and ideological aspects. Text, 8 , 91-111. 
Billig, M. (1988b). Rhetorical and historical aspects of attitudes: The case of the British monarchy. Philosophical Psychology, 1, 83-103.

Billig, M. (1989). The argumentative nature of holding strong views: A case study. European Journal of Social Psychology, 19, 203-23.

Billig, M. (1991). Ideologies and beliefs. London: Sage.

Billig, M. (1992). Talking of the royal family. London: Routledge.

Billig, M. (1995) Banal Nationalism. London; Sage.

Billig, M. (1996) in Hayes.

Billig, M., Condor, S., Edwards, D., Gane, M., Middleton, D.J. \& Radley, A.R. (1988). Ideological dilemmas: A social psychology of everyday thinking. London: Sage.

Boden, D. \& Zimmerman, D. (Eds.) (1991). Talk and social structure: Studies in ethnomethodology and conversation analysis. Cambridge: Polity.

Boden, D. (1994). The business of talk: The organization of action. Cambridge: Polity.

Brown, G., \& Yule, G. (1983). Discourse analysis. Cambridge: Cambridge University Press.

Burningham, K. (1995) Attitudes, accounts and impact assessment, The Sociological Review, $44,100-22$.

Buttny, R. (1993). Social accountability in communication. London: Sage.

Campbell, A. (1995) Representations, repertoires and power: Mother-child conflict. Journal for the Theory of Social Behaviour, 25, 35-57.

Clayman, S.E. (1992). Footing in the achievement of neutrality: The case of news-interview discourse. In P. Drew \& J. Heritage (Eds.), Talk at work: Interaction in institutional settings (pp. 163-198). Cambridge: Cambridge University Press.

Clayman, S.E. (1993). Booing: The anatomy of a disaffiliative response. American Sociological Review, 58, 110-130. 
Chalmers, A. (1992). What is this thing called science?: An assessment of the nature and status of science and its methods, 2nd Ed.. Milton Keynes: Open University Press.

Collins, H.M. (1985). Changing order: Replication and induction in scientific practice. London: Sage.

Coyle, A. (1995) Discourse analysis. In G.M. Breakwell, Hammond, S. \& Fife-Schaw, C. (Eds) Research Methods in Psychology. London; Sage.

Crano, W.D. \& Prislin, R. (1995) Components of vested interest and attitude-behaviour consistency, Basic and Applied Social Psychology, 17, 1-21.

Curt, B.C. (1994). Textuality and tectonics: Troubling social and psychological science. Buckingham, UK and Philadelphia, PA: Open University Press.

Drew, P. \& Heritage, J.C. (Eds.) (1992). Talk at work: Interaction in institutional settings. Cambridge: University of Cambridge Press.

Drew, P. (1984). Speakers' reportings in invitation sequences. In J.M. Atkinson and J.C. Heritage (Eds.) Structures of social action: Studies in conversation analysis (pp. 12951). Cambridge: Cambridge University Press.

Drew, P. (1995). Conversation analysis . In J. Smith, R. Harré, \& L. van Langenhove, \& P. Stearns (Eds.), Rethinking methods in psychology (pp. 64-79). London and Beverly Hills, CA: Sage.

Eagly, A.H. \& Chaiken, S. (1993). The psychology of attitudes. London; Harcourt Brace Jovanovich.

Edwards, D. (1991). Categories are for talking: On the cognitive and discursive bases of categorization. Theory and Psychology, 1, 515-542.

Edwards, D. (1994). Script formulations: A study of event descriptions in conversation. Journal of Language and Social Psychology, 13, 211-247. 
Edwards, D. (1995). Two to tango: Script formulations, dispositions, and rhetorical symmetry in relationship troubles talk. Research on Language and Social Interaction, $28(4), 319-50$.

Edwards, D. (1997). Discourse and Cognition. London: Sage.

Edwards, D. (forthcoming), Emotion discourse, Culture and Psychology.

Edwards, D., Ashmore, M. \& Potter, J. (1995). Death and furniture: The rhetoric, politics, and theology of bottom line arguments against relativism. History of the Human Sciences, 8, 25-49.

Edwards, D. \& Mercer, N.M. (1987). Common knowledge: The development of understanding in the classroom. London: Routledge.

Edwards, D. \& Potter, J. (1992a). Discursive psychology. London: Sage.

Edwards, D. \& Potter, J. (1992b). The chancellor's memory: Rhetoric and truth in discursive remembering. Applied Cognitive Psychology, 6, 187-215.

Edwards, D. \& Potter, J. (1993). Language and causation: A discursive action model of description and attribution. Psychological Review, 100, 23-41.

Fishbein, M. \& Azjen, I. (1975). Belief, attitude, intention and behaviour: An introduction to theory and research. Reading, MA: Addison-Wesley.

Fiske, S.T. \& Taylor, S.E. (1991) Social Cognition (2nd Ed.). New York; McGraw Hill.

Foucault, M. (1971). Orders of discourse. Social Science Information, 10, 7-30.

Garfinkel, H. (1967). Studies in ethnomethodology. Englewood Cliffs, NJ: Prentice-Hall.

Gergen, K. J. (1973). Social psychology as history. Journal of Personality and Social Psychology, 26, 309-20.

Gergen, K.J. (1991). The saturated self: Dilemmas of identity in contemporary life. New York: Basic Books. 
Gergen, K.J. (1994). Realities and relationships: Soundings in social construction. Cambridge, MA: Harvard University Press.

Gilbert, G. N. \& Mulkay, M. (1984). Opening Pandora's box: A sociological analysis of scientists' discourse. Cambridge: Cambridge University Press.

Gill, R. (1991) Ideology and popular radio: A discourse analytic investigation of disc jockey's talk, unpublished PhD thesis, Loughborough University.

Gill, R. (1993). Justifying injustice: Broadcasters' accounts on inequality in radio. In E. Burman \& I. Parker (Eds.), Discourse analytic research: Repertoires and readings of texts in action (pp. 75-93). London: Routledge.

Gill, R. (1995) Relativism, reflexivity and politics: Interrogating discourse analysis from a feminist perspective. In S. Wilkinson \& C. Kitzinger (Eds) Feminism and Discourse (pp. 165-186) London; Sage.

Gill, R. (1996) Discourse analysis: Methodological aspects. In J.E. Richardson (Ed.) Handbook of Qualitative Research Methods for Psychology and the Social Sciences (pp. 141-156). Leicester; British Psychological Society.

Grady, K. and Potter J. (1985). Speaking and clapping: A comparison of Foot and Thatcher's oratory. Language and Communication, 5, 173-83.

Harré, R. \& Secord, P. F. (1972). The explanation of social behaviour. Oxford: Blackwell. Harré, R. (1992). What is real in psychology? A plea for persons. Theory and Psychology, 2, 153-158.

Heath, C. (1992). The delivery and reception of diagnosis in the general-practice consultation. In P. Drew \& J. Heritage (Eds.), Talk at work: Interaction in institutional settings (pp. 235-267). Cambridge: Cambridge University Press.

Heritage, J.C. \& Greatbatch, D.L. (1986). Generating applause: A study of rhetoric and response at party political conferences. American Journal of Sociology, 92, 110-157. 
Heritage, J.C. \& Greatbatch, D.L. (1991). On the institutional character of institutional talk: The case of news interviews. In D. Boden \& D.H. Zimmerman (Eds.), Talk and social structure: Studies in ethnomethodology and conversation analysis (pp. 93-137). Oxford: Polity.

Heritage, J.C. (1984). Garfinkel and ethnomethodology. Cambridge: Polity.

Heritage, J.C. (1988). Explanations as accounts: A conversation analytic perspective. In C. Antaki (Ed.), Analysing everyday explanation: A casebook of methods (pp. 127-44). London: Sage.

Heritage, J.C. (1995). Conversation analysis: Methodological aspects. In U. Quasthoff (Ed.), Aspects of oral communication (pp. 391-418). Berlin and New York: De Gruyter.

Heritage, J.C. \& Greatbatch, D.L. (1991). On the institutional character of institutional talk: The case of news interviews. In D. Boden \& D.H. Zimmerman (Eds.), Talk and social structure: Studies in ethnomethodology and conversation analysis (pp. 93-137). Oxford: Polity.

Hovland, C.I., Janis, I.L., \& Kelley, H.H. (1953) Communication and Persuasion. New Haven, CT: Yale University Press.

Katz, D. (1960) The functional approach to the study of attitudes, Public Opinion Quarterly, 24, 163-204.

Levinson, S.C. (1983). Pragmatics. Cambridge: Cambridge University Press.

Litton, I. \& Potter, J. (1985). Social representations in the ordinary explanation of a 'riot.' European Journal of Social Psychology, 15, 371-88.

Lupton, D. \& Chapman, S. (1995) 'A healthy lifestyle might be the death of you': Discourses on diet, cholestrol control and heart disease in the press and among the lay public. Sociology of Health and Illness, 17, 477-94. 
Maio, G.R. \& Olson, J.M. (1994) Value-attitude-behaviour relations: The moderating role of attitude functions, British Journal of Social Psychology, 33, 301-12.

Marshall, H. \& Wetherell, M. (1989). Talking about career and gender identities: A discourse analysis perspective. In Skevington, S. \& Baker, D. (Eds) The Social Identity of Women (pp. *****). London; Sage.

McCreanor, T. (1989), Talking about race. In H. Yensen, K. Hague, and T. McCreanor, (Eds), Honouring the Treaty. Auckland; Penguin.

McKinlay, A. \& Potter, J. (1987). Model discourse: Interpretative repertoires in scientist's conference talk. Social Studies of Science, 17, 443-63.

McKinlay, A. (1988) The pattern in the weave: An account of Wittgenstein's remarks on meaning-in-use and of their relation to social psychology, unpublished $\mathrm{Ph} . \mathrm{D}$ thesis, University of St. Andrews.

Moscovici, S. (1984). The phenomenon of social representations. In R.M. Farr \& S. Moscovici (Eds.), Social representations (pp. 3-70). Cambridge: Cambridge University Press.

Mulhausler, P. \& Harré, R. (1990). Pronouns and people. Oxford: Basil Blackwell.

Mulkay, M. \& Gilbert, G.N. (1981). Putting philosophy to work: Karl Popper's influence on scientific practice. Philosophy of the Social Sciences, 11, 389-407.

Mulkay, M. \& Gilbert, G.N. (1982). Accounting for error: How scientists construct their social world when they account for correct and incorrect belief. Sociology, 16, 165-83.

Mulkay, M. \& Gilbert, G.N. (1983). Scientists' theory talk. Canadian Journal of Sociology, $8,179-97$.

Mulkay, M. \& Gilbert, G.N. (1985). Opening Pandora's box: A new approach to the sociological analysis of theory choice. Knowledge and Society, 5, 113-39. 
Mulkay, M. (1985). The word and the world: Explorations in the form of sociological analysis. London: Allen \& Unwin.

Myers, G. (1996) Displaying opinions: Disagreement and topic shifts in focus groups, ms. under submission.

Nairn, R. \& McCreanor, T. (1990) Insensitivity and hypersensitivity: An imbalance in Pakeha accounts of racial conflict, Journal of Language and Social Psychology, 9, 293-308.

Nairn, R. \& McCreanor, T. (1991) Race talk and common sense: Patterns in Pakeha discourse on Maori/Pakeha relations in New Zealand, Journal of Language and Social Psychology, 10, 245-62.

Nofsinger, R.E. (1991). Everyday conversation. London: Sage.

Norman, P. \& Smith, L. (1995) The theory of planned behaviour and exercise: An investigation into the role of prior behaviour, behavioural intentions and attitude variability, European Journal of Social Psychology, 25, 403-15.

Parker, I. (1989). The crisis in modern social psychology — and how to end it. London: Routledge.

Parker, I. (1992). Discourse dynamics: Critical analysis for social and individual psychology. London: Routledge.

Pomerantz, A.M. (1978). Compliment responses: notes on the co-operation of multiple constraints. In J. Schenkein (ed.), Studies in the organization of conversational interaction (pp. 79-98). London: Academic Press.

Pomerantz, A.M. (1984). Agreeing and disagreeing with assessments: Some features of preferred/dispreferred turn shapes. In J.M. Atkinson \& J. Heritage (Eds.), Structures of social action: Studies in conversation analysis (pp. 57-101). Cambridge: Cambridge University Press. 
Potter, J. (1984). Testability, flexibility: Kuhnian values in psychologists' discourse concerning theory choice. Philosophy of the Social Sciences, 14, 303-30.

Potter, J. (1987). Reading repertoires: A preliminary study of some techniques that scientists use to construct readings. Science and Technology Studies, 5, 112-21.

Potter, J. (1988). Cutting cakes: A study of psychologists' social categorizations. Philosophical Psychology, 1, 17-33.

Potter, J. (1995) Why psychologists should be interested in facts, Interamerican Journal of Psychology, 29, 91-103.

Potter, J. (1996a) Discourse Analysis. In A. Cupar (Ed.) Encyclopedia of the Social Sciences (pp. 188-9). London; Routledge.

Potter, J. (1996b) Representing Reality: Discourse, Rhetoric and Social Construction. London; Sage.

Potter, J. (1996c) Discourse anaysis and constructionist approaches: Theoretical background. In J.E. Richardson (Ed.) Handbook of qualitative research methods for psychology and the social sciences (pp. 125-140). Leicester; British Psychological Society.

Potter, J. (1997) Discourse analysis as a way of analysing naturally occurring talk. In D.

Silverman (Ed.) Qualitative Analysis: Issues of theory and method. London; Sage.

Potter, J. (forthcoming a) Fragments in the realization of relativism. In I. Parker (Ed.) Social Constructionism, Discourse and Realism. London; Sage.

Potter, J. (forthcoming b) Qualitative and discourse analysis. In N.R. Schooler (Ed.) Comprehensive clinical psychology: Volume 3: Research methods. Oxford: Elsevier Science.

Potter, J. \& Edwards, D. (1990). Nigel Lawson's tent: Discourse analysis, attribution theory and the social psychology of fact. European Journal of Social Psychology, 20, 24-40. 
Potter, J. \& Edwards, D. (1994). La construction d'une démission politique. In A. Trognon \& J. Larrue (Eds.), Pragmatique du discours politique. Paris: Armand Colin.

Potter, J. \& Litton I. (1985). Some problems underlying the theory of social representations. British Journal of Social Psychology, 24, 81-90.

Potter, J. \& Mulkay, M. (1985). Scientists' interview talk: Interviews as a technique for revealing participants' interpretative practices. In M. Brenner, J. Brown \& D. Canter (Eds.) The research interview: Uses and approaches. London: Academic Press.

Potter, J. \& Wetherell, M. (1987). Discourse and social psychology: Beyond attitudes and behaviour. London: Sage.

Potter, J. \& Wetherell, M. (1988). Accomplishing attitudes: Fact and evaluation in racist discourse. Text, 8, 51-68.

Potter, J. \& Wetherell, M. (1989). Fragmented ideologies: Accounts of educational failure and positive discrimination. Text, 9, 175-90.

Potter, J. \& Wetherell, M. (1994) Analyzing discourse. In A. Bryman and B. Burgess (Eds) Analyzing Qualitative Data (pp. 47-56). London; Routledge.

Potter, J. \& Wetherell, M. (1995) Discourse analysis. In J. Smith, R. Harré and L. van Langenhove (Eds) Rethinking Methods in Psychology (pp. 80-92). London; Sage.

Potter, J., Edwards, D. \& Wetherell, M. (1993) A model of discourse in action. American Behavioural Scientist, 36 (3), 383-401.

Prislin, R. (1996) Attitude stability and attitude strength: One is enough to make it stable, European Journal of Social Psychology, 26, 447-77.

Roffe, M. (1997) The interactional organization of social work, unpublished Ph.D thesis, Loughborough University.

Sabini, J. \& Silver, M. (1982). Moralities of everyday life. Oxford: Oxford University Press. 
Sacks, H. (1992). Lectures on conversation. Vols. I \& II, edited by G. Jefferson. Oxford: Basil Blackwell.

Sacks, H., Schegloff, E.A., \& Jefferson, G. (1974) A simplest systematics for the organization of turn-taking for conversation. Language, 50, 696-735.

Schegloff, E.A. (1995) Discourse as an interactional achievement III: The omnirelevance of action, Research on Language and Social Interaction, 28, 185-211.

Schegloff, E.A. (1997) Whose text? Whose Context?, Discourse and Society, 8, 165-187.

Schiffrin, D. (1994) Approaches to Discourse. Oxford; Blackwell.

Shavitt, S. (1990) The role of attitude objects in attitude functions, Journal of Experimental Social Psychology, 26, 124-48.

Shi-xu (1996) Cultural representations: Understanding Chinese and Dutch discourse about the other, unpublished Ph.D, University of Amsterdam.

Shotter, J. (1977) Images of Man in Psychological Research. London; Methuen.

Shotter, J. (1993a). Conversational realities: Constructing life through language. London: Sage.

Shotter, J. (1993b). Cultural politics of everyday life: Social constructionism, rhetoric and knowing of the third kind. Buckingham: Open University Press.

Sinclair, J. McH. \& Coulthard, R.M. (1975). Towards an analysis of discourse: The English used by teachers and pupils. London: Oxford University Press.

Sparks, P., Hedderley, D., \& Shepherd, R. (1992) An investigation into the relationship between perceived control, attitude variability and the consumption of two common foods, European Journal of Social Psychology, 22, 55-71.

Suchman, L. \& Jordan, B. (1990). Interactional troubles in face-to-face survey interviews. Journal of the American Statistical Association, 85, 232-41. 
te Molder, H. (1996) Discourse of dilemmas: An analysis of government communicators' talk, unpublished $\mathrm{Ph} . \mathrm{D}$, University of Wageningen.

Van Dijk, T.A. \& Kintch, W. (1983). Strategies of discourse comprehension. London: Academic Press.

van Dijk, T.A. (1996) Discourse Studies: A multidisciplinary introduction(2 Vols). London; Sage.

Wetherell, M. \& Potter, J. (1992) Mapping the Language of Racism: Discourse and the legitimation of exploitation. London; Harvester, New York; Columbia University Press.

Wetherell, M. (forthcoming) Fear of fat. Feminism and Psychology, [?].

Wetherell, M., Stiven, H. and Potter, J. (1987) Unequal egalitarianism: a preliminary study of discourses concerning gender and employment opportunities. British Journal of Social Psychology, 26, 59-71.

Widdicombe, S. \& Wooffitt, R. (1995). The language of youth subcultures: Social identity in action. Hemel Hempstead, UK: Harvester/Wheatsheaf.

Wooffitt, R. (1992). Telling tales of the unexpected: The organization of factual discourse. London: Harvester/Wheatsheaf.

Wooffitt, R. (1993). Analysing accounts. In N. Gilbert (Ed.), Researching social life (pp. 287305). London and Beverly Hills, CA: Sage.

Wooffitt, R.C. (1990). On the analysis of interaction: An introduction to conversation analysis. In P. Luff, D. Frohlich \& G.N. Gilbert (Eds.), Computers and conversation (pp. 7-38). New York: Academic Press.

Woolgar, S (1988). Science: The very idea. London; Tavistock. 
Zanna, M.P. and Rempel, J.K. (1988) Attitudes: A new look at an old concept. In Bar-Tal, D. \& Kruglanski, A.W. (Eds) The Social Psychology of Knowledge (pp. 315-34). Cambridge: Cambridge University Press. 